\title{
One-stage deammonification start-up control using ion-selective electrodes (ISE) sensor
}

\author{
Stanisław Miodoński ${ }^{1, *}$, and Mateusz Muszyński-Huhajło \\ ${ }^{1}$ Faculty of Environmental Engineering, Wroclaw University of Science and Technology, \\ Plac Grunwaldzki 9, 50-377 Wroclaw, Poland
}

\begin{abstract}
Dynamic development of side-stream ammonia-rich streams treatment technologies creates need of new methods of control techniques. So far, most of available technologies are based on relatively simple sensors, such as $\mathrm{pH}$ probes. This article presents the results of an ion selective electrode used for controlling a one-stage deammonification process in the start-up period. Sensor applicability under alternating aerobic/anaerobic conditions and large fluctuations of measured substances concentrations was investigated. ISE probe was also used to verify Anammox bacteria response on elevated dissolved oxygen exposition at the beginning of the anaerobic phases preceded by aerobic phases.
\end{abstract}

\section{Introduction}

Discovery of anaerobic ammonium oxidation (Anammox) had great impact on biological nitrogen removal (BNR) process development [1]. An important trend in recent years is to focus on turning away from traditional nitrification-denitrification path and try to make deammonification a main tool for nitrogen removal from wastewater [2]. Current state of knowledge about this process limits its application to high-strength ammonium streams (i.e. centrate water from sludge dewatering), named as side-stream treatment. Robust deammonification in cold streams with low ammonium concentration, such as municipal wastewater (mainstream treatment), is still subject of intense research and should be considered as an infancy stage so far [3-6]. Until 2014, there was over 100 full-scale side-stream installations, where $88 \%$ of them was in one-stage reactor configuration, which means that partial nitritation and Anammox (PN/Anammox) processes occur in a single reactor [7].

Considering fact, that characteristics of nitritation and Anammox process are completely different, operating one-stage installation for such processes is a great challenge. Especially in context of dissolved oxygen (DO) control, which, as necessary for nitrifiers and, on the other hand, critical for Anammox biomass, must be kept at certain level to avoid affecting both processes. It was reported, that Anammox bacteria was reversibly inhibited by low DO concentrations $(<1-2 \%$ air saturation) and irreversibly by higher DO concentrations ( $>18 \%$ air saturation) [8]. In general, Anammox bacteria are

* Corresponding author: stanislaw.miodonski@pwr.edu.pl 
considered as difficult to cultivate due to low growth rate and biomass yield and high sensitivity to environmental conditions [9].

This study describes the use of an ion-selective electrode (ISE) ammonium and nitrate probe during a start-up of a one-stage PN/Anammox process in a pilot-scale SBR treating real centrate water from sludge dewatering at a Polish large (over 500000p.e.) wastewater treatment plant (WWTP). Aim of this paper was to highlight potential benefits/threats derived from using this type of measuring devices in such advanced process.

\subsection{PN/Anammox process}

\subsubsection{Anammox}

Discovery of anaerobic ammonium oxidation, was a revolutionary step towards more efficient N-removal in wastewater treatment [10]. In general, Anammox is an anaerobic multi-stage process which stoichiometry is given by Eq. 1[11]. Described group of microorganisms are autotrophic bacteria using inorganic carbon for biomass yield.

$$
\begin{gathered}
\mathrm{NH}_{4}^{+}+1,32 \mathrm{NO}_{2}^{-}+0,066 \mathrm{HCO}_{3}^{-}+0,13 \mathrm{H}^{+} \rightarrow \\
1,02 \mathrm{~N}_{2}+0,066 \mathrm{CH}_{2} \mathrm{O}_{0,5} \mathrm{~N}_{0,15}+0,26 \mathrm{NO}_{3}^{-}+2,03 \mathrm{H}_{2} \mathrm{O}
\end{gathered}
$$

\subsubsection{Partial nitritation}

Contrary to traditional nitrification-denitrification pathway of nitrogen removal, for Anammox purposes, only partial oxidation of ammonium to nitrite is required (see Eq. 1) To achieve this state, constant suppression of nitrite oxidizing bacteria (NOBs) is required along with stable ammonium/nitrite ratio around 1.3, which is suitable for Anammox process. Selective inhibition of NOBs can be achieved by creating proper operating conditions in the reactor, such as: high free ammonia/nitrous acid concentrations [12], low dissolved oxygen concentrations [13] or elevated temperature [14]. As nitritation consumes alkalinity due to two protons production per mole of oxidized ammonium, final $\mathrm{NO}_{2} / \mathrm{NH}_{4}$ ratio depends on influent alkalinity and may be controlled by $\mathrm{pH}$ maintained in the reactor [15]. Necessity of only partial oxidation of ammonium in this processes reduces net oxygen required for nitrogen removal to $1.71 \mathrm{mg} \mathrm{O} / 2 \mathrm{mg} \mathrm{N}-\mathrm{NH}_{4}$ converted into gas if influent biodegradable organic matter is used to denitrify residual $\mathrm{N}-\mathrm{NO}_{\mathrm{x}}[16]$.

\subsection{On-line monitoring for wastewater treatment}

Development of advanced and more complex technologies used in wastewater treatment would not be possible without development in the field of products used to gather and process information about conditions of ongoing treatment processes. The end of $90 \mathrm{~s}$ of 20th century brought a distinct change in process control at WWTPs as number of new chemical and physical on-line sensors became popular along, as well as the earlier spread of SCADA (Supervisory Control and Data Acquisition) systems. It became possible to measure practically all significant parameters in real-time at each stage of wastewater treatment and allowed to create new control strategies based on so called "safety points". Such control allows to run predefined preventive or repair procedure in case of violation one of set points values, enhancing process stability [17]. 
To optimize side-stream treatment nitrogen removal, ISE sensors for on-line ammonium and nitrate concentrations measurement demonstrated their usefulness as well as luminescent dissolved oxygen sensors. These advanced tools in combination with control algorithms allowed to optimize aeration process for nitrification purposes [18, 19]. Direct measurement of nitrogen compounds concentration allows to precisely control biological nitrogen removal processes, which is commonly used in mainstream treatment (i.e. aeration control based on $\mathrm{N}^{-\mathrm{NH}_{4}}$ concentration profile [20]) and can be easily adopt for side-stream treatment purposes (i.e. control of aeration phases duration for achieving appropriate $\mathrm{N}-\mathrm{NH}_{4} / \mathrm{N}-\mathrm{NO}_{2}$ ratio in deammonification process). The obvious benefit from the use of such in-situ sensors is quick and automatic collection of information on key parameters for installation operation. Ex-situ meters require additional sampling device and proper sample preparation (usually filtration) before measurement itself, which increases the level of complexity of the measuring system and extends the time from sampling to obtain information. The specificity of mentioned measurement methods makes in-situ sensors more favourable due to lower operational and maintenance costs, however they require regular calibration and verification of their indications [21, 22].

\section{Materials and methods}

\subsection{Experimental set-up}

\subsubsection{Pilot scale SBR}

Start-up was performed in a 150L SBR treating real reject-liquor from digested sludge dewatering. Reactor was operated at predefined time cycles, consisting of filling, mixing with intermittent aeration, sedimentation, decantation phases. Reactor was equipped with number of sensors connected to SCADA system providing parental control of following parameters: temperature, $\mathrm{pH}, \mathrm{DO}$ level, filling/decanting volume and mixing intensity. $\mathrm{N}-\mathrm{NH}_{4} / \mathrm{N}-\mathrm{NO}_{3}$ ISE probe was installed in the reactor without connection to SCADA and was used to modify SBR operating parameters manually by the operator. Reactor scheme was shown in the Figure 1.

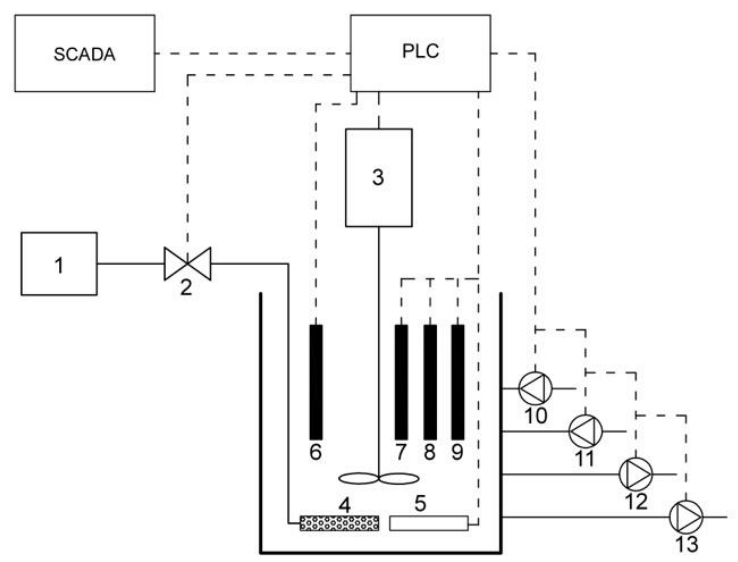

1 - blower

2 - regulation valve

3 - mixer

4 - membrane plate diffuser

5 - heater

6 - AN-ISE $\mathrm{NH}_{4} / \mathrm{NO}_{3}$ probe

7 - DO probe

8 - $\mathrm{pH} /$ REDOX probe

9 - hydrostatic probe

10 - influent punp

11 - pH control pump

12 - excess sludge pump

13 - effluent pump

PLC - Programmable Logic

Controller

Fig. 1. Pilot scale SBR set-up. 


\subsubsection{Treated medium characteristics}

Pilot installation treated real centrate from sludge dewatering collected from a belt press without flushing water used for belt cleaning to avoid excessive dilution. Sludge processed in dewatering unit was after mesophilic digestion process (HRT about 40d). Due to intermittent operation of belt press, centrate was collected periodically in a storage tank to provide supply of influent medium for SBR. After each filling, medium composition was determined. During start-up period, typical influent ammonium concentration, and alkalinity were equal $660 \mathrm{~g} \mathrm{~N}-\mathrm{NH} 4 / \mathrm{m}^{3}$ and $56 \mathrm{~g} \mathrm{CaCO}_{3} / \mathrm{m}^{3}$, respectively.

\subsubsection{Combined $\mathrm{N}-\mathrm{NH}_{4}$ and $\mathrm{N}-\mathrm{NO}_{3} \mathrm{AN}-\mathrm{ISE}$ Sensor}

Due to major role in presented study, more specific details about Hach's (Germany) AN-ISE combined ammonium and nitrate probe are presented in this section. In pilot SBR, a single probe of this type is installed and connected to Hach's Universal Controller Display Module SC1000, providing on-line measurements and data recording. AN-ISE probe contains ion-selective electrodes with special membranes, that only specific type of ion can adhere. Potential difference between selective electrode and reference electrode occurs, proportionally to measured $\mathrm{NH}_{4}{ }^{+} / \mathrm{NO}_{3}{ }^{-}$ion concentration. Interference of potassium and chloride when measuring ammonium and nitrate, respectively, are compensated by built-in electrodes. To prevent electrodes contamination, a compressed air cleaning unit is periodically used. Except that, probe was manually cleaned once a week during presented experiment. Sensor calibration was performed based on regular verification of its indications with a reference method (Hach's cuvette tests - indophenol blue method for ammonium and 2,6-dimethylphenol method for nitrate). Each time, full matrix correction protocol was used $\left(\mathrm{NH}_{4}{ }^{+}+\mathrm{K}^{+}, \mathrm{NO}_{3}{ }^{-}+\mathrm{Cl}^{-}\right)$for calibration. Table 1 summarizes selected information about AN-ISE sensor provided by the manufacturer [23].

Table 1. AN-ISE sensor specification [23].

\begin{tabular}{|c|c|c|}
\hline Parameter & Value & Comments \\
\hline Measurement range & $0-1000 \mathrm{mg} / \mathrm{dm}^{3}$ & $\begin{array}{c}\mathrm{N}^{-N_{4}}, \mathrm{~N}- \\
\mathrm{NO}_{3}, \mathrm{~K}+, \mathrm{CL}-\end{array}$ \\
\hline Accuracy & $\pm 5 \%+0.2 \mathrm{mg} / \mathrm{dm}^{3}$ & $\begin{array}{c}\% \text { measured } \\
\text { value }\end{array}$ \\
\hline Response time & $<3 \mathrm{~min}$ & - \\
\hline Sample pH range & $5-9$ & - \\
\hline Sample temperature range & $2-40^{\circ} \mathrm{C}$ & - \\
\hline
\end{tabular}

\subsubsection{Analytical methods.}

Collected samples were filtered with syringe filters, pore size $1.2 \mu \mathrm{m}$ and after that ammonia, nitrite and nitrate nitrogen concentrations were measured using Hach photometric cuvette tests: LCK303 $\left(2-47 \mathrm{mg} \mathrm{N}-\mathrm{NH}_{4}{ }^{+} / \mathrm{dm}^{3}\right)$, LCK342 (range $0.6-6 \mathrm{mg} \mathrm{N}-\mathrm{NO}_{2}{ }^{-} / \mathrm{dm}^{3}$ ) and LCK340 (range 5-35 $\mathrm{mg} \mathrm{N}^{3} \mathrm{NO}_{3}^{-} / \mathrm{dm}^{3}$ ) and a DR3900 spectrophotometer. Total suspended solids (TSS) and volatile suspended solids (VSS) concentrations were determined using direct weight method according to Standard Methods guideline. 


\subsection{One-stage deammonification start-up}

Start-up of one-stage deammonification process was performed in a SBR treating centrate from sludge dewatering. Sludge inoculum for the process was taken from full-scale deammonification installation at another WWTP, where, due to technical issues, side-stream installation was not operated for over two months. In this case, described actions can be considered as attempt to re-start the whole process. As the main objective of the experiment was to achieve stable $\mathrm{PN} /$ Anammox process operating at nitrogen loading rate $(\mathrm{NLR})$ over $0.2 \mathrm{~kg} \mathrm{~N}-\mathrm{NH}_{4} \cdot\left(\mathrm{m}^{3} \cdot \mathrm{d}\right)^{-1}$.

Start-up was preceded by a series of lab-scale tests to evaluate PN and Anammox process rates in the inoculum. Based on gained results, initial NLR has been determined and process started. SBR was operated in 3 hour cycles. Single cycle consisted of: one filling phase at the beginning (time adjusted depending on NLR), 7 aeration phases ( 5 to 7 minutes, adjusted based on process efficiency) separated by anoxic phases. Total reaction phase took 126 minutes with continuous mixing. At the end of each cycle 20-40 minutes were provided for sludge settling and 5-10 minutes for effluent decantation. Cycle scheme during described period is presented in Figure 1.

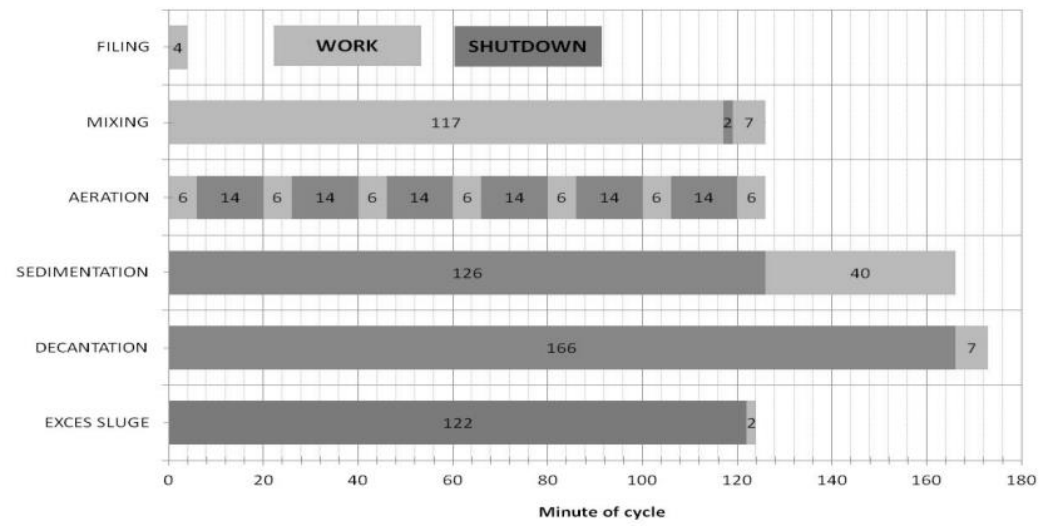

Fig. 1. SBR cycle scheme during the start-up period.

Process was operated under the similar conditions to the full-scale installation: temperature $27^{\circ} \mathrm{C}, \mathrm{pH}=7.1$, DO in the aeration phase $0.4-1.0 \mathrm{mg} \mathrm{O} / \mathrm{dm}^{3}$. NLR and aeration time was adjusted daily by the operator based on $\mathrm{N}$-compounds concentration in the effluent (analytical method) and $\mathrm{N}-\mathrm{NH}_{4}{ }^{+} / \mathrm{N}_{-} \mathrm{NO}_{3}{ }^{-}$profiles from the AN-ISE probe. NLR and effluent quality is presented in Figure 2.

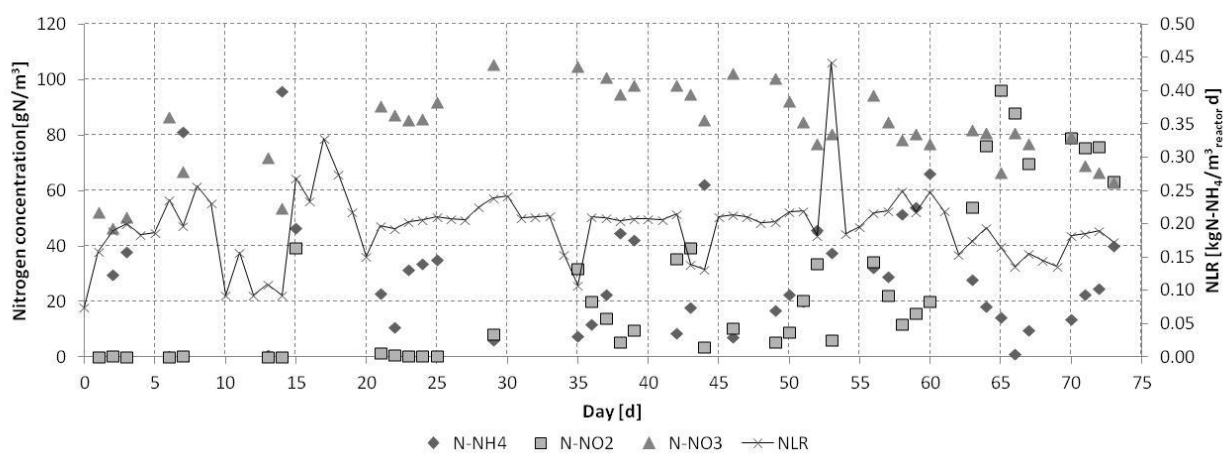

Fig. 2. SBR effluent composition (daily average) and NLR during the start-up period. 


\section{Results}

\subsection{Ammonium uptake rate (AUR) in oxic / anaerobic conditions}

Ammonium concentration was continuously measured using the AN-ISE probe. Each day of start-up period, an average AUR for aerobic and anaerobic conditions was calculated for single SBR cycle. AUR under aerobic conditions mostly represented reduction of ammonium concentration due to activity of ammonium oxidizing bacteria (AOBs). Notable decrease of $\mathrm{NH}_{4}{ }^{+}$level during anaerobic conditions can be explained by the Anammox bacteria activity.

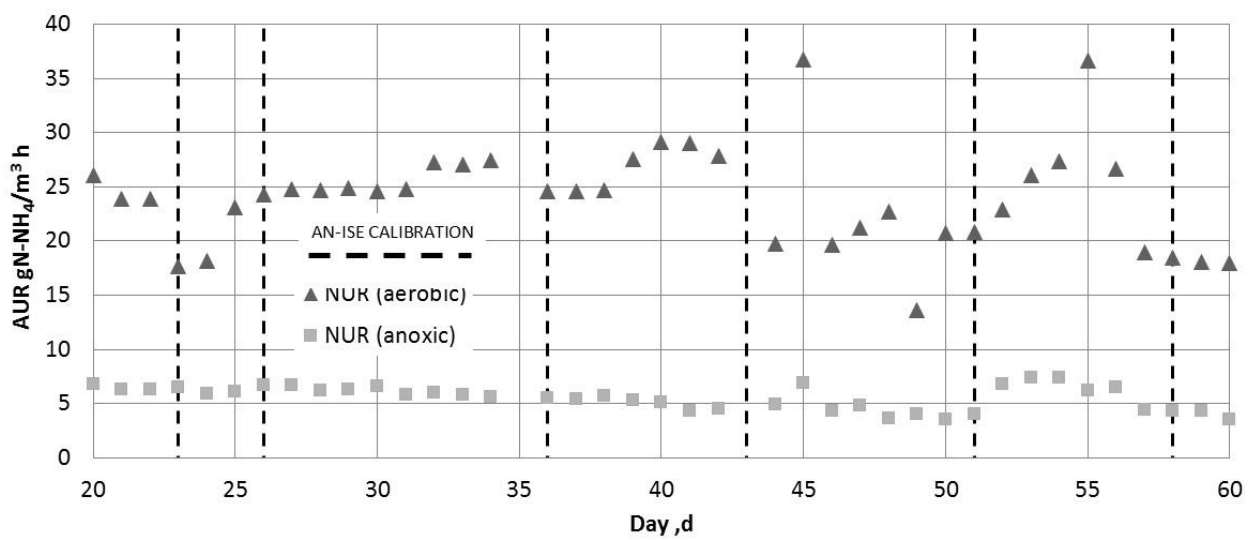

Fig. 3. Average anoxic and aerobic AUR rates during the start-up period. Dashed lines indicates sensor calibration.

Figure 3 presents daily average AUR values for anaerobic and aerobic conditions calculated from AN-ISE measurements in selected single cycle each day. Dashed vertical lines indicates days when sensor calibration was performed. During first 43 days of experiment, average AUR value for aerobic and anaerobic conditions showed no significant variations and were, on average, equal $24.44 \mathrm{~g} \mathrm{~N}-\mathrm{NH} 4 \cdot\left(\mathrm{m}^{3} \cdot \mathrm{h}\right)^{-1}$ (SD: $\left.4.56 \mathrm{~g} \mathrm{~N}^{-\mathrm{NH}} 4\left(\mathrm{~m}^{3} \cdot \mathrm{h}\right)^{-1}\right)$ and $5.88 \mathrm{~g} \mathrm{~N}-\mathrm{NH} 4\left(\mathrm{~m}^{3} \cdot \mathrm{h}\right)^{-1} \quad\left(\mathrm{SD}: \quad 1.25 \mathrm{~g} \mathrm{~N}-\mathrm{NH} 4 \cdot\left(\mathrm{m}^{3} \cdot \mathrm{h}\right)^{-1}\right)$, respectively. After that period, slight reduction of these values occurred, probably due to periodic $\mathrm{NH}_{4}$ and $\mathrm{NO}_{2}$ accumulation (see Fig. 2) resulting in elevated free ammonia / free nitrous acid concentrations causing bacterial activity inhibition. In this period, aerobic AUR was $22.77 \mathrm{~g} \mathrm{~N}-\mathrm{NH} 4 \cdot\left(\mathrm{m}^{3} \cdot \mathrm{h}\right)^{-1}\left(\mathrm{SD}: 5.56 \mathrm{~g} \mathrm{~N}-\mathrm{NH} 4 \cdot\left(\mathrm{m}^{3} \cdot \mathrm{h}\right)^{-1}\right)$ and anaerobic AUR was $4.73 \mathrm{~g} \mathrm{~N}-\mathrm{NH} 4 \cdot\left(\mathrm{m}^{3} \cdot \mathrm{h}\right)^{-1}\left(\mathrm{SD}: 1.48 \mathrm{~g} \mathrm{~N}-\mathrm{NH} 4 \cdot\left(\mathrm{m}^{3} \cdot \mathrm{h}\right)^{-1}\right)$. Despite these observations, it can be clearly noticed that significant impact on measured AUR values has time elapsed since sensor calibration. Changes in sensor parameters did not occurred linearly (whole indication curve did not shift up or down), which may cause big differences in AUR values before and right after re-calibration.

\subsection{Lag phase in Anammox activity after aeration phase.}

Return of Anammox bacteria to their normal activity at the beginning of anaerobic phases was investigated. After end of each aeration phase, DO level in the reactor dropped below $0.1 \mathrm{mg} \mathrm{O} / \mathrm{dm}^{3}$ in less than 40 seconds due to presence of ammonium and nitrifiers activity. After that short time, a stagnation of ammonium concentration decrease was still noticeable due to Anammox lag phase after period of inhibition due to elevated dissolved oxygen presence. Using the AN-ISE probe length of the lag phase was measured based on 
the ammonium concentration at different stages of the start-up. Results are presented in Figure 4. It can be clearly noticed, that a clear suppression of Anammox activity occurred for several minutes $(5-7 \mathrm{~min})$ in the first days of the experiment. After 25 days, such phenomenon was reduced to less than one minute, what suggests possible Anammox adaptation to periodic aerobic conditions and reduction of the time needed to restore its normal metabolism.
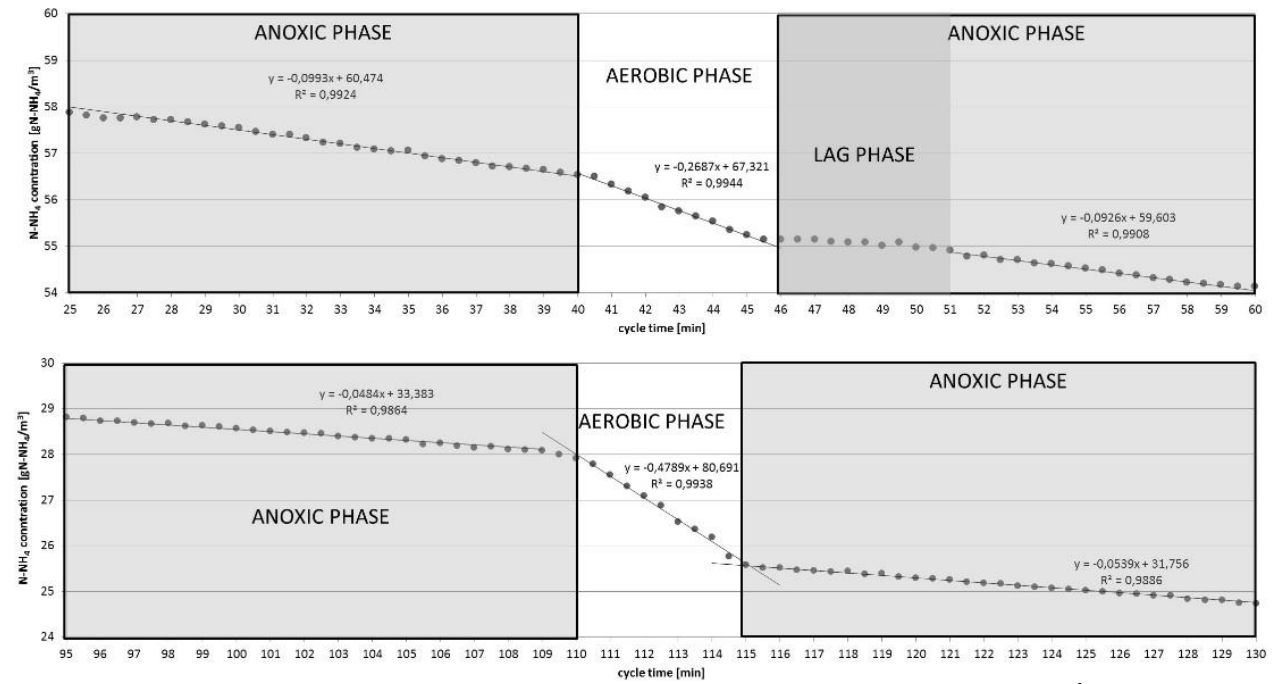

Fig. 4. Anammox lag phase after aerobic phase at the beginning of start-up day $22^{\text {th }}$, (upper) and at $63^{\text {th }}$ day of experiment (lower).

\section{Conclusions}

- Ion Selective Electrode for ammonium and nitrate measurements can be a useful tool during a one-stage deammonification process start-up and operation. Quick and reliable information about process condition can be helpful in daily control and detection of stability disturbances connected with ammonium accumulation or unwanted activity of NOBs resulting nitrite concentration growth.

- AUR determination using AN-ISE probe during aerobic and anaerobic conditions is possible only when time between calibrations is short enough. In reactor where large fluctuations of measured values occur, sensor indications quality are quickly decreasing. To keep gained data at certain level of accuracy frequent calibrations are needed, more than once a week.

- Observed Anammox inhibition due to alternating aerobic/anoxic conditions was only periodical despite relatively high DO concentrations for such process (up to $1 \mathrm{~g} \mathrm{O}_{2} / \mathrm{m}^{3}$ ). During described process start-up, adaptation of Anammox bacteria to periodic aerobic conditions was identified as a reduction of the lag phase in the ammonium decrease after the aerobic phase. Remarkable reduction of the lag phase was observed, from 5-7 minutes at the beginning of the experiment to less than

a minute after 25 days. fact indicates that AN-ISE probe can be successfully used in tests of factors affecting processes which result in ammonium concentration change. 
The authors gratefully acknowledge co-funding from the National Centre for Research and Development (grant no PBS2/B9/25/2014) and Municipal Water and Sewage Company Wroclaw.

\section{References}

1. A. Mulder, A.A. van de Graaf, L.A. Robertson, J.G. Kuenen, Fems Microbiol Ecol, 16, 177-183 (1995)

2. M.C. van Loosdrecht, D. Brdjanovic, Science, 344, 1452-1453 (2014)

3. G. Xu, Y. Zhou, Q. Yang, ZM. Lee, J. Gu, W. Lay, Y. Cao, Y. Liu, Appl Microbiol Biot, 99, 2485-2490 (2015)

4. B. Wett, S.M. Podmirseg, M. Gomez-Brandon, M. Hell, G. Nyhuis, C. Bott, S. Murthy, Water Environ Res, 87, 2084-2089 (2014)

5. P. Regmi, M.W. Miller, R. Bunce, D.M. Hingley, D. Kinnear, B. Wett, S. Murthy, C.B. Bott, WEFTEC. 15, 1994-2017 (2012)

6. R. Lemaire, H. Zhao, C. Thomson, M. Christensson, S. Piveteau, S. Hemmingsen, F. Veuillet, P. Zozor, J. Ochoa, WEFTEC. 6, 2183-2197 (2014)

7. S. Lackner, E.M. Gilbert, S.E.Vlaeminck, A. Joss, H. Horn, M.C.M. Van Loosdrecht, Water Research, 55, 292-303 (2014)

8. R.C. Jin, G.-F. Yang, J.J. Yu, P. Zheng, Chem Eng J 197, 67-79 (2012)

9. M. Strous, J.A. Fuerst, E.H.M. Kramer, S. Logemann, G. Muyzer, K.T. van de PasSchoonen, R. Webb, J.G. Kuenen, M.S.M. Jetten, Nature $400446-449$ (1999)

10. M.M.M. Kuypers, G. Lavik, D. Woebken, M. Schmid, B.M. Fuchs, R. Amann, B.B. Jørgensen, M.S.M. Jetten., P Natl Acad Sci USA, 102, 6478-6483 (2005)

11. M. Strous, J.J. Heijnen, J.G. Kuenen, M.S.M. Jetten, Microbiol Biot, 50, 589-596 (1998)

12. A.C. Anthonisen, R.C. Loehr, T.B.S. Prakasam, E.G. Srinath, J Water Pollut Con F, 48, 835-852 (1976)

13. R. Blackburne, Z. Yuan, J. Keller, Biodegradation, 19, 303-312 (2008)

14. M.S.M. Jetten, S. Logemann, G. Muyzer, L.A. Robertson, S. de Vries, M.C.M. van Loosrecht, J.G. Kuenen, A Van Leeuw J Microb, 71, 75-93 (1997)

15. C. Fux, M. Boehler, P. Huber, I. Brunner, H. Siegrist, Water Res, 99, 295-306 (2002)

16. G.T. Daigger, Water Environ Res 86, 204-209 (2014)

17. K.P. Tsagarakis, K. Stamatelatou, Sewage Treatment Plants: Economic Evaluation of Innovative Technologies for Energy Efficiency, IWA Publishing (2015).

18. D. Jenkins, J. Wanner, Activated sludge: 100 years and counting, IWA Publishing, 2014

19. L. Åmand, G. Olsson, B. Carlsson., Water Sci Technol, 67, 2374-2398 (2013)

20. H. Siegrist, L. Rieger, C, Fux, M. Wehrli, Water Sci Technol, 50, 35-43 (2004)

21. S. Winkler, L. Rieger, E. Saracevic, A. Pressl, G. Gruber, Water Sci Technol, 50, 105-114 (2004)

22. D. Kaelin, J. Eugster, K. Rottermann, C. Banninger, H. Siegrist, Water Sci Technol, 58, 6-29 (2008)

23. AN-ISE sc: Combination sensor for ammonium and nitrate - Data Sheet, HACH (2012) 